\title{
1. Clarifying the law of passing off
}

\section{INTRODUCTION}

The foundational principle for the aptly named 'law of passing off' is that a trader should not deceive or mislead consumers ${ }^{1}$ and other members of the public by passing off its ${ }^{2}$ goods or services ${ }^{3}$ as the goods or services of another trader. The law has evolved through judicial decisions in common law jurisdictions primarily over the past two centuries. Over the past century, courts have justified their intervention as a way of protecting traders' goodwill from misrepresentation. Yet the concept of 'goodwill' remains ambiguous among legal authorities. On the one hand, it suggests a meaning that is almost synonymous with reputation or business goodwill in terms of the customers that a business attracts by its reputation. This work refers to this meaning as 'substantive goodwill'. On the other hand, 'goodwill' suggests a meaning that refers to the public recognition that the goods originate from or are associated in some way with a trader with its approval. This work refers to this meaning as 'structural goodwill'. This ambiguity in the meaning of 'goodwill' has caused inconsistencies in the law. ${ }^{4}$ One example analysed later is the most recent decision on

1 For simplicity, unless the context suggests otherwise, 'consumers', 'purchasers', 'customers', 'clientele' and 'relevant public' are used interchangeably to indicate the persons making the purchase decision. Consumers are not necessarily purchasers and vice versa. For example, parents often make purchase decisions for their children, who are the ultimate consumers of the goods. The relationship between purchasers and consumers varies widely.

2 Because the law of passing off largely deals with traders and commercial organizations, this work uses the third person singular pronoun 'it' to refer to a trader, unless the context suggests otherwise. For consistency, this work also uses 'plaintiff' throughout to include 'claimant' - a synonymous term used in some jurisdictions, unless 'claimant' is used in a quotation from those jurisdictions. 'Plaintiff' is also used to refer to the party which is claiming or likely has a right to claim under the law discussed in the context.

3 The term 'goods' includes goods and services, unless the context indicates otherwise.

4 This conceptual bifurcation should be distinguished from the terms that some use in the US to address the geographical scope of trade mark rights by dividing the zone of 'actual goodwill' between a 'zone of actual market penetration' where a trader enjoys 
the law of passing off delivered by the United Kingdom (UK) Supreme Court. This work considers the law of passing off in Australia, common law Canada, England and Wales and the federal level of the United States of America (US).

It seeks to clarify this ambiguity and proposes that structural goodwill should be the primary object of protection under the law of passing off. This clarity is important for three reasons. First, it renders the law of passing off internally coherent. The House of Lords once declared passing off as the 'most protean' among unfair trading wrongs actionable at the suit of other traders that suffer consequential loss of business or goodwill. ${ }^{5}$ The Federal Court of Australia also found that the law of passing off contained 'sufficient nooks and crannies to make it difficult to formulate any satisfactory definition in short form '. ${ }^{6}$ Since then, as discussed in Chapter 4, the law of passing off has continued to expand its scope of protection.

Second, clarity in the law of passing off is important to rationalize part of the increasingly complex trade mark regimes in the jurisdictions under consideration. While the law of passing off does not deal exclusively with trade mark laws, as a strand of unfair competition law, it often overlaps with trade mark laws and, in some jurisdictions, offers a further cause of action for trade mark registrants. One way in which traders often pass off their goods as those of others is by using those other traders' trade marks. ${ }^{7}$ However, the law of passing off need not involve 'trade marks' in the sense defined in legislation. ${ }^{8}$ Even where trade marks are involved, the law of passing off takes into consideration the overall presentation of the disputed materials, including disclaimers, which are extraneous to trade marks. On the other hand, modern trade

goodwill from the sale of its goods and a 'zone of reputation' where a trader enjoys goodwill developed through advertising or word of mouth. See Thomas F Cotter, 'Owning What Doesn't Exist, Where It Doesn't Exist: Rethinking Two Doctrines from the Common Law of Trademarks' (1995) 1995 U Ill L Rev 487, 495.

5 Erven Warnink Besloten Vennootschap v J Townend \& Sons (Hull) Ltd [1979] AC 731 (HL) (Advocaat) 740.

6 ConAgra Inc v McCain Foods (Aust) Pty Ltd [1992] FCA 159 (Full Court) [13].

7 For simplicity, the term 'trade mark' includes service marks and trade dress. 'Trade dress' is the total image of a product or a service business including the shape and other elements making up the general appearance or even particular sales techniques - see Two Pesos Inc v Taco Cabana Inc 505 US 763 (1992) 787 footnote 1. For consistency, 'trade mark' is used throughout, except in quotations from the US and Canada, where 'trademark' or 'trade-mark' was used in the jurisdiction at the time.

8 Australia: Trade Marks Act 1995, s 17. Canada: Trademarks Act, RSC 1985, c T-13, s 2. UK: Trade Marks Act 1994, s 1 (intellectual property matters such as trade marks are reserved to the UK government under s 27 in Schedule 3 of the Northern Ireland Act 1998, s C4 in Schedule 5 of the Scotland Act 1998 (as amended 2012 and 2016), s C4 in Schedule 7A of the Wales Act 2017, while the law of passing off operates under common law - see n 63). US: Lanham Act $\$ 45$. 
mark laws often redress more than passing off. For example, some laws protect trade marks with a reputation from having their repute tarnished by traders which use them without due cause and, importantly, without misleading or confusing consumers. ${ }^{9}$ As discussed in Chapter 5, such trade mark protection beyond that against passing off remains contentious among legal scholars. The focus of this work is on the law of passing off as a cause of action independent of trade mark laws and also as a legal principle against unfair competition within trade mark laws.

Finally, by clarifying the law of passing off, this work seeks to steer the law clear of the inherent conflict which may result when it misplaces its focus on protecting substantive goodwill. It also seeks to place the law in a better position to rationalize its stance vis-à-vis other intellectual property rights such as copyright and publicity rights. The relationship between the law of passing off and other intellectual property rights is a theme that threads through this work.

This work argues that the law of passing off should maintain its focus on protecting structural goodwill even though structural goodwill and substantive goodwill are intertwined. Protecting a trader's structural goodwill also incidentally protects to some degree the substantive goodwill that pertains to the trader. This work argues that plaintiffs need not establish prima facie 'goodwill' in advancing a claim under the law of passing off as they currently tend to do, and as the law appears to demand in Australia, Canada and England and Wales. Rather, 'goodwill' in the sense of structural goodwill is implicit in any confusion or likelihood of confusion that results from the misrepresentation that the law of passing off redresses. ${ }^{10}$

This chapter first elaborates on the concepts of substantive goodwill and structural goodwill, and this duality in goodwill. It then sets out the legal framework that constitutes the law of passing off in the jurisdictions considered here. Furthermore, it sets out the raisons d'être for this work. Finally, it considers the jurisdictional coverage and the scope and format of this work.

\section{SUBSTANTIVE GOODWILL}

The term 'substantive goodwill' as proposed in this work refers to the part of goodwill that has substantive value contents. These contents consist of 'the

9 For example, UK: Trade Marks Act 1994, s 10(3). US: Lanham Act §43(c). See also Graeme B Dinwoodie, 'Non-Traditional Marks in Europe: Conceptual Lessons from their Apparent Demise?' NYU Colloquium, Draft of 4 February 2019, www .law.nyu.edu/sites/default/files/upload_documents/Graeme\%20Dinwoodie.pdf (last accessed 7 August 2020) 16-17. [49]. 
attractive force which brings in custom'11 for a business. As Chapters 2 and 4 demonstrate, authorities often cite this phrase for the 'goodwill' protected under the law of passing off. The phrase originates from an English case, The Commissioners of Inland Revenue v Muller \& Co's Margarine (IRC), determining the ad valorem duty on a transaction that included certain goodwill under the Stamp Act, 1891. Lord Macnaghten explained it there as 'the benefit and advantage of the goodwill, reputation, and connection of a business'. ${ }^{12}$ Lord Lindley gave examples 'to include whatever adds value to a business by reason of situation, name and reputation, connection, introduction to old customers, and agreed absence from competition, or any of these things', ${ }^{13}$ among others. US authority on passing off often cites a similar definition that originates from partnership law, ${ }^{14}$ as explained further in Chapter 2. These definitions show goodwill - in the sense referred to here as 'substantive goodwill' - as embodying substantive value on its own to offer consumers.

One example of substantive goodwill in respect of the plastic Lego toy bricks lies in the innovative design of the bricks, giving them 'clutch power'. Lego bricks have studs on the top which fit snugly within the side walls and the round, hollow tubes underneath the Lego bricks above. This innovative 'stud-and-tube' technology allows the bricks to be assembled and disassembled with ease. It also allows cantilevers to be constructed with Lego bricks that hitherto were not easily achievable. This 'clutch power' not only opened up the play potential of the bricks, but also positioned the bricks as the base elements for Lego to sell accoutrements such as trees and road signs to enhance the play experience. Thus began the System of Play. ${ }^{15}$ The stage was set for endless combinations and permutations of creations. This system allows Lego to sell more than toy bricks. By merchandising accoutrements, Lego engages consumers in more immersive experiences in their creativity. ${ }^{16}$ By collaborating with other traders, Lego garners more diverse 'benefit[s] and advantage[s] of the goodwill, reputation' for the business than through the sale of toy bricks alone. Lego's co-branding with the Star Wars and DC Comics Super Heroes franchises is among the examples discussed below and in Chapter 3.

11 The Commissioners of Inland Revenue v Muller \& Co's Margarine [1901] AC 217 (HL) (IRC) 224.

12 Ibid 223-24.

13 Ibid 235.

14 See text to $\mathrm{n} 40$ in Chapter 2.

15 David Robertson, Brick by Brick: How Lego Rewrote the Rules of Innovation and Conquered the Global Toy Industry (Kindle edn, Random House 2013), Chapter 1, Third Principle: 'Not a Product but a System'.

16 Mark JP Wolf, 'Adapting the Death Star into Lego: The Case of Lego Set \#10188' in Mark JP Wolf (ed), Lego Studies: Examining the Building Blocks of a Transmedial Phenomenon (Routledge 2014) 18-20, 28-29. 
However, as also explored further in Chapter 3, the substantive value or 'attractive force' is seldom the construct of any trader alone. Traders, consumers and commentators refer to branded goods both intentionally and inadvertently. In doing so, they contribute to the substantive goodwill that pertains to the relevant trader. For example, Dyson reportedly enjoyed a sudden spike in sales when its air purifying fan was caught by chance in a photograph of Queen Elizabeth II's meeting with the UK prime minister in Buckingham Palace. ${ }^{17}$ Other variables, such as a change of social zeitgeist (eg, towards environmental concerns), may also impact on the substantive goodwill pertaining to a trader that is not immediately within the trader's control. Therefore, substantive goodwill is seldom entirely within the control of any one trader, no matter what resources that trader invests in its goods and their promotion. Furthermore, the value-laden nature of substantive goodwill can attract consumers as well as alienate them. For example, some erstwhile potential Dyson consumers might refrain from purchasing Dyson goods as a result of the photograph. 'Once the brand is offered to the world, consumers and communities may engage with and sometimes reinterpret or repurpose the brand.' ${ }^{18}$ To facilitate this engagement, and indeed freedom of expression in the marketplace as well as social spaces, no trader has or should have exclusive control over the substantive goodwill that pertains to it or its goods.

\section{STRUCTURAL GOODWILL}

'Structural goodwill' as proposed here denotes the public recognition of the provenance of the goods not only in the sense of their trade origin, but also in the broader sense of their selection by the trader for sale or endorsed association. 'Structural' goodwill is so called because it offers a structure for consumers to organize in their minds what each trader in the marketplace sells as goods of its own or, more broadly, goods it endorses by association. For

17 For example, Zoe Wood, 'Dyson Fan Flies Off the Shelves After Being Spotted in Royal Photo', The Guardian (26 July 2019), www.theguardian.com/technology/ 2019/jul/26/the-dyson-fan-which-keeps-the-queen-cool (last accessed 7 August 2020) was from a search at Google.co.uk on 7 August 2020, among at least 15 news and magazine websites reporting on this and targeting UK, US, Indian and Australian readerships. Some were actively promoting the sale of Dyson fans through the story. See, for example, Hannah Coates, 'This is How the Queen is Keeping Cool in the Heatwave', Vogue (25 July 2019), www.vogue.co.uk/article/queen-uses-dyson-fan-in-heat (last accessed 7 August 2020); Charley Ward, 'This Dyson Fan is Fit for the Queen', Good Housekeeping (25 July 2019), www.goodhousekeeping.com/uk/house-and-home/ a28506946/dyson-fan-queen-heatwave/ (last accessed 7 August 2020).

18 Deven R Desai, 'From Trademarks to Brands' (2012) 64 Fla L Rev 981, 999, 1009. 
example, the Virgin brand - which has a portfolio that ranges from financial services to telecommunications and travel - has a different structure in consumers' minds from the Lego brand, which centres its offerings on toy bricks. On the other hand, Lego also extends its market presence through theme parks and associations with the Star Wars and DC Comic Super Heroes franchises. Unlike substantive goodwill, structural goodwill on its own has no substantive value content to attract custom. Rather it is the relevant public's recognition of a trader as the source or endorser of the branded goods in the marketplace.

\section{THE DUALITY OF GOODWILL}

Structural goodwill and substantive goodwill are intertwined. Structural goodwill pulls together a composite view of a trader's goods and endorsements that informs consumers about the substantive goodwill in respect of the trader. For example, even though some of its earlier patents on the 'clutch power' technology of its bricks have lapsed, Lego still ranked $75^{\text {th }}$ among the world's most valuable brands in 2019. ${ }^{19}$ Lego's presence in the marketplace remains far greater than the tiny imprints of the 'Lego' mark on its bricks and on their packaging. Lego has extended its offerings and thus its structural goodwill to Legoland theme parks to appeal to young fans. Through Lego's association with science fiction and superhero themes, fans can also build transmedial creations on those themes with Lego bricks. Movies such as The Lego Movie (2014), The Lego Batman Movie (2017) and The Lego Movie 2: The Second Part (2019) set the scenes. Playsets such as Lego Star Wars and Lego Batman enable fans to use toy bricks to access big-screen fantasy. Lego's first movie grossed nearly $\$ 500$ million and Lego reported a 25 per cent sales increase in the year after its release. ${ }^{20}$ Lego's structural goodwill connecting its mark in the public consciousness with cultural icons such as Star Wars and Batman channels the substantive goodwill in those icons to Lego bricks and vice versa. While Lego's substantive goodwill attracts custom, its structural goodwill is the conduit that links up all the Lego goods and endorsements in the minds of the relevant public. The extension of structural goodwill to associate Lego

19 Interbrand, 'Best Global Brands 2019 Rankings', www.interbrand.com/best -brands/best-global-brands/2019/ranking/ (last accessed 12 August 2020); see also Mike Rocha, 'Where's the Value in Brand Valuation? Addressing the Debate', www .interbrand.com/views/wheres-the-value-in-brand-valuation-addressing-the-debate (last accessed 12 August 2020).

20 Interbrand, 'The End of Positioning: Introducing Iconic Moves', in Interbrand, Best Global Brands 2019 (2019), www.interbrand.com/best-brands/best-global -brands/2019/articles/the-end-of-positioning-introducing-iconic-moves/ (last accessed 12 August 2020). 
bricks with science fiction and superheroes makes the bricks more attractive to consumers. It adds to Lego's substantive goodwill, beyond the initial substantive goodwill in toy bricks with 'clutch power'. So when a consumer comes across a block-shaped superhero figure with 'clutch power' hands and bearing the Lego mark, the consumer can assume it is from Lego. If it is not, there may be passing off. In turn, substantive goodwill deepens the consumer's view of how the brand is positioned in the marketplace vis-à-vis competitive and complementary goods. It sets Star Wars and Batman-associated Lego bricks apart from other toy bricks in the consumer's mind. It informs how traders may successfully extend structural goodwill. Lego's status as a toy brand with an adult following makes its association with Star Wars compatible.

While the two aspects of goodwill are intertwined, it is important to differentiate how the law should protect substantive goodwill as it pertains to a trader, as opposed to a trader's structural goodwill. The substantive goodwill that pertains to Lego may be harmed by altering Lego's esteem in the eyes of its relevant public (eg, by views about whether the bricks contain substances that are potentially harmful to children). Lego's structural goodwill may be harmed only by misattributing (including non-attributing) Lego goods or endorsements in the minds of the consuming public.

Exceptionally, some goods (eg, perfumes and goods bearing certain product designs) are such that these two aspects of goodwill are not easily separable, as discussed in a post-sale context in Chapter 4. The focus of concern for this work is on the more common scenarios where the two aspects of goodwill are intertwined in discrete coexistence.

\section{THE LAW OF PASSING OFF}

The law of passing off seeks to redress the misattribution of traders' goods and endorsements. The term 'passing off' has a different meaning in jurisdictions such as Australia, Canada and England and Wales on the one hand, and in the US on the other. In Australia, Canada and England and Wales, 'passing off' is a term of art that denotes a branch of economic torts. ${ }^{21}$ This work uses the term in this specific sense as detailed below. In the US, 'passing off' understood in this sense is a part of unfair competition law and includes the infringement of unregistered trade marks. This should be differentiated from other uses of the term 'passing off' in US law. ${ }^{22}$ Australia, Canada and England and Wales on the one hand, and the US on the other, draw from different sources

21 Hazel Carty, An Analysis of the Economic Torts (OUP 2010) 225.

22 J Thomas McCarthy, McCarthy on Trademarks and Unfair Competition (5th edn, Thomson Reuters online R June 2020) [25:1]. 
of law. They are thus analysed separately throughout this work. In both sets of jurisdictions, the law of passing off intervenes regardless of whether the misattribution alters the esteem of a brand in the eyes of the relevant public. Its objective is not to protect a brand's esteem; rather, it protects the accurate public attribution of traders' goods and endorsements where such attribution is relevant to consumers' purchase decision making.

\subsection{Australia, Canada and England and Wales}

The current iteration of the law of passing off in Australia, Canada and England and Wales primarily protects structural goodwill. Courts in these jurisdictions have adopted the 'classic trinity' test that constitutes the law of passing off today. ${ }^{23}$ The three elements of the test are often pithily summarized as goodwill; misrepresentation leading to or likely to lead to consumer confusion; and harm or likelihood of harm to plaintiffs. Lord Oliver set out these elements more fully in an English case commonly known as the Jif Lemon case:

First, [the plaintiff] must establish a goodwill or reputation attached to the goods or services which he supplies in the mind of the purchasing public by association with the identifying 'get-up' (whether it consists simply of a brand name or a trade description, or the individual features of labelling or packaging) under which his particular goods or services are offered to the public, such that the get-up is recognised by the public as distinctive specifically of the plaintiff's goods or services. Secondly, he must demonstrate a misrepresentation by the defendant to the public (whether or not intentional) leading or likely to lead the public to believe that goods or services offered by him are the goods or services of the plaintiff. Whether the public is aware of the plaintiff's identity as the manufacturer or supplier of the goods or services is immaterial, as long as they are identified with a particular source which is in fact the plaintiff. For example, if the public is accustomed to rely upon a particular brand name in purchasing goods of a particular description, it matters not at all that there is little or no public awareness of the identity of the proprietor of the brand name. Thirdly, he must demonstrate that he suffers or, in a quia timet action that he is likely to suffer, damage by reason of the erroneous belief engendered by the defendant's misrepresentation that the source of the defendant's goods or services is the same as the source of those offered by the plaintiff. ${ }^{24}$

The facts of Jif Lemon typify a case of 'classic passing off', where the disputing parties' goods are readily substitutable for each other's. Here, a rival

23 Australia: ConAgra (n 6) [29]-[30], [69] (Lockhart J), [12], [13] (Gummow J). Canada: Ciba-Geigy Canada Ltd v Apotex Inc [1992] 3 SCR 120 [30], [32], [33]; Kirkbi $A G v$ Ritvik Holdings Inc 2005 SCC 65 [66]. England and Wales: Starbucks (HK) Ltd v British Sky Broadcasting Group Plc [2015] UKSC 31, [2015] 1 WLR 2628 [15]-[17].

24 Reckitt and Colman Products Ltd v Borden Inc [1990] 1 WLR 491, 499 (emphasis added). 
trader sold lemon juice in a way that made it likely that consumers would confuse the distinct lemon-shaped packaging of the plaintiff's goods with its own lookalike packaging. Courts in Australia, Canada and England and Wales apply this classic trinity test to a wide range of fact scenarios, beyond classic passing off, to find passing off in advertising, merchandising, endorsement and in some cases post-sale confusion, which occurs when the goods are in use or in a downstream market, as analysed in Chapter 4.

Notably, the first element of goodwill in this test refers to structural goodwill. The wording in Jif Lemon does not require that consumers have any knowledge about the plaintiff or its goods. Indeed, it does not require consumers to have had any prior encounter with the plaintiff or its goods. It requires only that consumers recognize from the trade marks or identifiers that the underlying goods are the plaintiff's (whoever it may be). Nevertheless, the use of 'goodwill or reputation' is potentially ambiguous, as 'reputation' may refer to substantive goodwill.

If the element of goodwill in the Jif Lemon test refers exclusively to structural goodwill - in other words, the link in the consumer's mind that connects a trader's goods with the trader through the trade mark or identifier on those goods - then the three elements of the tort need not be interpreted as three distinct thresholds that a plaintiff must meet. ${ }^{25}$ Case law has long maintained that 'one man may quite well pass off his goods as the goods of another if he passes them off to people who will accept them as the manufacture of another, though they do not know that other by name at all ${ }^{26}$ or have in mind the particular individual who made the goods they purchase.

The same principle is echoed in Jif Lemon, as highlighted in the quotation. Even though in Jif Lemon, Lord Oliver applied the test as consisting of three distinct and sequential thresholds, he did so with a clear view that the first element referred strictly to structural goodwill. If consumers cannot recognize the plaintiff's goods, it is difficult for them to mistakenly attribute another trader's goods as those of the plaintiff.

The focus of the tort is on misrepresentation. The first and third elements of goodwill and harm respectively qualify the type of misrepresentation to misattribution and quantify the extent to which it is likely to cause harm to the plaintiff to constitute an actionable tort in passing off. Thus, where there is already actual consumer confusion or likelihood of confusion and harm to the plaintiff, the lack of a showing of 'goodwill' should not be an obstacle to

25 Robert Burrell and Michael Handler, Australian Trade Mark Law (2nd edn, OUP 2016) 490, 528.

26 The Birmingham Vinegar Brewery Company Ltd v Powell [1897] AC 710 (HL) 715. See also for Canada: Oxford Pendaflex Canada v Korr Marketing Ltd [1982] 1 SCR 494 [20]. 
the plaintiff in succeeding in its passing off claims. Nevertheless, a showing of structural goodwill can help to demonstrate that harm to it is likely as a result of the defendant's misrepresentation.

Under this construction, the Jif Lemon test should not be construed as a test posing three separate thresholds. However, case law routinely applies the test by posing three separate thresholds. Treating goodwill as a separate and prima facie threshold to constitute the tort opens the test to including substantive goodwill or business reputation as a requisite part of the element. ${ }^{27}$ One example is the UK Supreme Court case of Starbucks (HK) Ltd v British Sky Broadcasting Group Plc. ${ }^{28}$ The UK Supreme Court required not only that the plaintiffs had customers located in England and Wales, but also that they had developed their clientele in England and Wales in order to constitute the element of goodwill as an independent threshold under the law of passing off, ${ }^{29}$ even though the plaintiffs had already established the other elements of passing off - namely misrepresentation likely to lead to consumer confusion and likelihood of harm to the plaintiff. ${ }^{30}$ As discussed in Chapter 4 , the decision has attracted considerable criticism.

Before the classic trinity test set out in Jif Lemon, Australia and Canada also adopted Lord Diplock's principles of passing off from the 1979 English case known as Advocaat. ${ }^{31}$ Those principles begin with the misrepresentation perpetrated in passing off. The case dealt with a Dutch liqueur called 'advocaat' which had been exported to and become well known in England. The essential ingredients were specifically regulated under Dutch law. The defendants marketed a similar drink in England called 'Keeling's Old English Advocaat' which contained different ingredients. Even though the public had not con-

27 For example, England and Wales: Churton v Douglas (1859) VC Johnson 174, 188, 70 ER 385, 391; IRC (n 11) 223-24; My Kinda Bones Limited v Dr Pepper's Stove Co Ltd [1984] FSR 289 (Ch) 299. US: Menendez v Holt 128 US 514 (1888) 521-22; Joseph Story, Commentaries on the Law of Partnership, as a Branch of Commercial and Maritime Jurisprudence with Occasional Illustrations from the Civil and Foreign Law (Charles C Little \& James Brown 1841) §99-\$100; James L Hopkins, The Law of Unfair Trade: Including Trade-Marks, Trade Secrets, and Good-Will (Callaghan \& Company 1900) §61-\$63; Harry A Nims, The Law of Unfair Competition and Trade-Marks (2nd edn, Baker, Voorhis and Company 1921) 32-35. See also Tim W Dornis, Trademark and Unfair Competition Conflicts (CUP 2017) 95-99. Issues with this vague, inclusive approach were noted in England as early as Wedderburn $v$ Wedderburn (No 4) (1856) 22 Beavan 84, 104, 52 ER 1039, 1047; in the US: Premier-Pabst Corp v Elm City Brewing Co 9 F Supp 754 (D Conn 1935) 757, 760.

28 Starbucks (n 23). See also in Australia: Interlego v Croner [1992] FCA 624 [137].

Starbucks (n 23) [67].

30 Ibid [17]; see Chapter 4 for further discussion of this case.

31 Advocaat (n 5). 
fused the defendants' drink with the Dutch liqueur, Lord Diplock accepted that by using the word 'advocaat' in the name of its liqueur, the defendants were passing off their liqueur as belonging to the plaintiffs' class of regulated 'advocaat' drink and potentially damaging the plaintiffs' goodwill associated with it. After reviewing key case law in passing off, Lord Diplock summarized the law as comprising:

five characteristics which must be present in order to create a valid cause of action for passing off: (1) a misrepresentation (2) made by a trader in the course of trade, (3) to prospective customers of his or ultimate consumers of goods or services supplied by him, (4) which is calculated to injure the business or goodwill of another trader (in the sense that this is a reasonably foreseeable consequence [rather than an intention to harm]) and (5) which causes actual damage to a business or goodwill of the trader by whom the action is brought or (in a quia timet action) will probably do so. ${ }^{32}$

Lord Diplock recognized that 'misrepresentation' was a broad term to apply to passing off cases and warned that the presence of these five characteristics would not necessarily give rise to an action in passing off. For example, defamation and injurious falsehood fall within this five-part test, but do not necessarily constitute passing off.

Also in Advocaat, Lord Fraser offered five elements that a plaintiff must show to succeed in a passing off case:

(1) that his business consists of, or includes, selling in England a class of goods to which the particular trade name applies; (2) that the class of goods is clearly defined, and that in the minds of the public, or a section of the public, in England, the trade name distinguishes that class from other similar goods; (3) that because of the reputation of the goods, there is goodwill attached to the name; (4) that he, the plaintiff, as a member of the class of those who sell the goods, is the owner of goodwill in England which is of substantial value; (5) that he has suffered, or is really likely to suffer, substantial damage to his property in the goodwill by reason of the defendants selling goods which are falsely described by the trade name to which the goodwill is attached. ${ }^{33}$

While Lord Diplock's formulation lacks specificity as to the nature of the misrepresentation required in a passing off claim, Lord Fraser's formulation fills the gap by highlighting the distinguishing function of the mark in his second element. However, the requirement in the fourth element of the substantial value in the goodwill sees 'owning' substantive goodwill as a prerequisite to a trader claiming substantial harm to 'its' goodwill under the fifth element.

$32 \quad$ Ibid 742.

33 Ibid 755-56. 
Lord Diplock too accepted Lord Macnaghten's conception of 'goodwill' from $I R C$ and thus saw the misrepresentation required as injuring and causing damage to 'the attractive force which brings in custom ${ }^{34}$ under the fourth and fifth elements of his test.

The classic trinity test in Jif Lemon improves ${ }^{35}$ on both Lord Diplock's and Lord Fraser's formulations in Advocaat. While Lord Diplock's formulation places 'misrepresentation' at the forefront of the analysis, the Jif Lemon test tightens 'misrepresentation' to 'misattribution' by setting out 'goodwill' in the first element as the object misrepresented. The test in Jif Lemon is unambiguous in its focus on structural goodwill, both as the first element of the test and in its application in the case. While Lord Jauncey in Jif Lemon cited Lord Diplock's formulation in Advocaat followed by Lord Macnaghten's conception of goodwill from $I R C$, he added his conception of goodwill in structural terms, as 'that which associates the goods with the plaintiff in the mind of the public', ${ }^{36}$ and cautioned against the risk of granting monopolistic rights which could hamper competition. Lord Oliver, who set out the classic trinity test, did not cite Advocaat.

This work focuses on the classic trinity test as set out in Jif Lemon because it is now widely applied by the courts in Australia, Canada and England and Wales as the preferred test. Advocaat (as well as Jif Lemon) is nevertheless often cited in cases dealing with shared goodwill or extended passing off. Extended passing off has been described by the English Court of Appeal as 'a class action ... [where] the proprietary right [in goodwill] is shared by a number of potential claimants, all of whom produce the protected products' ${ }^{37}$ It is beyond the scope of this work and merits consideration on its own once the groundwork for 'goodwill' is established here.

This work argues that the protection against passing off should not depend on the presence or value of any substantive goodwill that pertains to the plaintiff. Instead, the protection of structural goodwill under the law allows the relevant public to authenticate their perception of the plaintiff's efforts in shaping the substantive goodwill (if any) that pertains to it. The object of protection under the law of passing off lies in the authenticity of the goods and of other forms of public communications (through advertising, endorsement and other means) that are attributed to the plaintiff. It protects the plaintiff from being falsely or misleadingly attributed as the source or the endorser of

34 Ibid 741.

35 This improvement is noted in Consorzio Del Prosciutto di Parma v Marks \& Spencer [1991] RPC 351 (CA) 368-70.

36 Jif Lemon (n 24) 418.

37 Fage UK Limited v Chobani UK Limited [2014] EWCA Civ 5, [2014] ETMR 26 [123]. 
the messages conveyed. It does not protect the plaintiff from the messages themselves, whatever their origin.

\subsection{The US}

In the US, Section 43(a)(1)(A) of the Lanham Act (15 USC §1125) sets out the most recent US federal codification of the substantive equivalent of the law of passing off as discussed here. ${ }^{38}$ It is sometimes called (rather than 'passing off') the 'false designation of origin' or more broadly, 'unfair competition' provision, while Section 43(a)(1)(B) deals with false advertising. These provisions read:

43(a)(1) Any person who, on or in connection with any goods or services, or any container for goods, uses in commerce any word, term, name, symbol, or device, or any combination thereof, or any false designation of origin, false or misleading description of fact, or false or misleading representation of fact, which -

(A) is likely to cause confusion, or to cause mistake, or to deceive as to the affiliation, connection, or association of such person with another person, or as to the origin, sponsorship, or approval of his or her goods, services, or commercial activities by another person, or

(B) in commercial advertising or promotion, misrepresents the nature, characteristics, qualities, or geographic origin of his or her or another person's goods, services, or commercial activities,

shall be liable in a civil action by any person who believes that he or she is or is likely to be damaged by such act.

Section 43(a)(1)(A) includes classic passing off and reaches beyond. It includes confusion 'as to the affiliation, connection, or association of such person with another person, or as to the origin, sponsorship, or approval of his or her goods, services, or commercial activities by another person'. As discussed in Chapter 4, these are areas that the law of passing off in Australia, Canada and England and Wales has also come to protect under the classic trinity test as set out in Jif Lemon. ${ }^{39}$

While the term 'goodwill' is not mentioned in Section 43(a)(1)(A), case law has established that 'the trademark laws [such as the Lanham Act] are designed not only to prevent consumer confusion but also to protect "the synonymous right of a trademark owner to control his product's reputation". ${ }^{40}$ The US

\footnotetext{
McCarthy (n 22) [25:1].

Two Pesos (n 7) 777-86.

Lois Sportswear USA Inc v Levi Strauss \& Co 799 F2d 867 (2d Cir 1986) 872, citing Dallas Cowboys Cheerleaders Inc v Pussycat Cinema Ltd 604 F2d 200 (2d Cir 1979) 205, citing James Burrough Ltd v Sign of Beefeater Inc 540 F2d 266 (7th Cir
} 1976) 274. 
Supreme Court has long noted that the function of trade marks is "simply to designate the goods as the product of a particular trader and to protect his good will against the sale of another's product as his'. ${ }^{41}$ The US Supreme Court also held in another case that requiring more of plaintiffs would be anti-competitive and unfair to start-ups which were yet to establish much presence in the marketplace. ${ }^{42}$ Nevertheless, US law protects traders' exclusive right to use their marks or identifiers only once they have used those marks or identifiers in commerce. ${ }^{43}$ Such use launches a trader's goodwill in the marketplace and can become circumstantial evidence or a proxy to indicate the presence of a trader's public recognition. ${ }^{44}$ The analysis here is on the protection of goodwill, rather than on trade mark use. US jurisprudence considers 'good will and its tangible symbol, a trademark, [as] inseparable'. ${ }^{45}$ While extending protection based on the presence of goodwill pertaining to the plaintiff and extending that protection based on the presence of the plaintiff's trade mark use overlap to a significant degree, contentious gaps exist between the two, ${ }^{46}$ as discussed in Chapter 4.

Section 43(a)(1)(A) of the Lanham Act trains its focus on the defendant's acts. Nevertheless, scholars and this work support a requirement in the law of passing off of a likelihood of harm to the plaintiff that is assessed based on the saliency that the defendant's actions have on consumers' decision making. ${ }^{47}$ The consumer confusion that results from the misrepresentation need not

\footnotetext{
${ }^{41}$ United Drug Co v Theodore Rectanus Co 248 US 90 (1918) 97; Desai (n 18) 1012.

42 Two Pesos (n 7) 775; see also McCarthy (n 22) [16.6] Author's Comment.

43 Hanover Star Milling Co v Metcalf 240 US 403 (1916) 413; McCarthy (n 22) [16:1.50].

44 Stacey L Dogan and Mark A Lemley, 'Grounding Trademark Law through
} Trademark Use' (2007) 92 Iowa L Rev 1669, 1689; Lee Ann W Lockridge, 'Honoring International Obligations in U.S. Trademark Law: How the Lanham Act Protects Well-Known Foreign Marks (and Why the Second Circuit Was Wrong)' (2010) 84 St John's L Rev 1347, 1403; Jake Linford, 'Valuing Residual Goodwill after Trademark Forfeiture' (2017) 93 Notre Dame L Rev 811, 843-44; Adam Mossoff, 'Trademark as a Property Right' (2018) 107 Ky L J 1, 30.

45 McCarthy (n 22) [2.15], [2.16].

46 Graeme B Dinwoodie, 'Trademarks and Territory: Detaching Trademark Law from the Nation-State' (2004) 41 Hous L Rev 885.

47 For example, Perini Corporation v Perini Construction Inc 915 F2d 121 (4th Cir 1990) 128; Mark A Lemley and Mark McKenna, 'Irrelevant Confusion' (2010) 62 Stanford L Rev 413, 451, 453; Mark A Lemley and Mark P McKenna, 'Owning Mark(et)s' (2010-11) 109 Mich L Rev 137, 141, 188; Mark P McKenna, ‘A Consumer Decision-Making Theory of Trademark Law' (2012) 98 Va L Rev 67, 125-36; Laura A Heymann, 'The Scope of Trademark Law in the Age of the Brand Persona' (2012) 98 Va L Rev Brief 61, 63-69; Kal Raustiala and Christopher Jon Sprigman, 'Rethinking Post-Sale Confusion' (2018) 108 Trademark Rep 881, 903. 
involve consumers knowing much about the plaintiff or its goods. In respect of confusion about the origin of the goods, '[i]t is, of course, not necessary that [the plaintiff] should be known as the maker; on the contrary, it will suffice if the article be known as coming from a single, though anonymous, source' ${ }^{48}$

Therefore, facially, Section 43(a)(1)(A) of the Lanham Act appears to focus on the use in commerce of trade marks and identifiers to misattribute a trader's goods as those of another or to misattribute a trader's endorsement of another's goods that could result in consumer confusion. If so, it includes the law of passing off in protecting structural goodwill. However, as discussed in Chapter 4, the US Supreme Court has not consistently interpreted the provision as such. This has created conceptual issues. More damagingly, as discussed in Chapter 6, the US Supreme Court appears to have ruled against the application of Section 43(a)(1)(A) of the Lanham Act to 'communicative products' at least in part in view of the protection already conferred under the Visual Artists Rights Act (VARA, 17 USC §106A) on authors' claims for attribution on certain 'communicative products'. As a result, swathes of 'communicative products' that are not protected under VARA are now unprotected from misattribution even if they are likely to cause consumer confusion.

\section{THE RAISONS D'ETRE FOR THIS WORK}

It is therefore crucial that the plumb line for protection against passing off be drawn brightly in contradistinction to other intellectual property rights across the jurisdictions under consideration here.

While US scholars have built on the distinction between the informational function and the persuasive function of trade marks, ${ }^{49}$ the term 'goodwill' within the context of passing off remains unclear..$^{50}$ Brown noted in his seminal article 'Advertising and the Public Interest' that trade symbols as a form of

48 Coty Inc v Le Blume Import Co 292 F 264 (SDNY 1923) 267-68. See also Menendez (n 27) 520; Shredded Wheat Co v Humphrey Cornell Co 250 F 960 (2d Cir 1918) 963; Manhattan Shirt Co v Sarnoff-Irving Hat Stores 19 Del Ch 151 (1933) 164 A 246, 250 affirmed 20 Del Ch 455 (1934).

49 See, for example, Ralph S Brown Jr, 'Advertising and the Public Interest: Legal Protection of Trade Symbols' (1948) 57 Yale L J 1165; Jessica Litman, 'Breakfast with Batman: The Public Interest in the Advertising Age' (1999) 108 Yale L J 1717; Glynn S Lunney Jr, 'Trademark Monopolies' (1999) 48 Emory L J 367; Katya Assaf, 'Brand Fetishism' (2010) 43 Conn L Rev 83, 105.

50 Brown (n 49) 1199-1200; Irene Calboli, 'Trademark Assignment with Goodwill: A Concept Whose Time Has Gone' (2005) 57 Fla L Rev 771, 775, 802, 804-08, 814. See also Neal R Platt, 'Good Will Enduring: How to Ensure That Trademark Priority Will Not Be Destroyed by the Sale of a Business' (2009) 99 Trademark Rep 788, 808; Linford (n 44) 815. 
advertising served two main functions: to inform and to persuade. ${ }^{51}$ "Nothing more than information as to source is necessary for the consumer to be able to repeat a satisfactory purchase'; 52 while 'the persuasive function of trade symbols is of dubious social utility. There seems little reason why the courts should recognize or protect interests deriving from it. ${ }^{53}$ The informational function of trade marks helps consumers to locate the desired goods. The persuasive function allows traders to promote the sale of goods through the use of trade marks. ${ }^{54}$ However, the dividing line between 'information' and 'persuasion' remains difficult to draw. Modern scholars ${ }^{55}$ see consumers' impression of the 'atmospherics' projected through trade marks or identifiers as an integral part of consuming branded goods. Litman mused: 'What kids want [from cereal] isn't a nutritious part of a complete breakfast; they want Batman to have breakfast with them. One box supplies that; the other doesn't.' ${ }^{56}$

European courts, in interpreting the European trade mark directives and regulations that are relevant to interpreting the UK Trade Marks Act 1994, also distinguish between marks which function to indicate the origin of the goods and marks which serve other functions such as communication, investment and advertising. While European courts recognize the origin distinguishing function of trade marks as essential, they also indicate that the other trade mark functions may also attract legal protection. ${ }^{57}$ The rationale for such protection remains unclear. The UK Trade Marks Act 1994 implemented the First (EU) Council Directive 89/104/EEC of 21 December 1988 to approximate the laws of the Member States relating to trade marks and its successors, and made provision in connection with Council Regulation (EC) No 40/94 of 20 December 1993 on the Community trade mark and its successors. ${ }^{58}$ Even though at the printing of this work, the UK will have exited from the European Union

\footnotetext{
Brown (n 49) 1183.

Ibid 1181.

Ibid 1190, 1201; see also 1194 on trade mark dilution.

See, for example, ibid 1189.

55 For example, Litman (n 49); Shahar J Dilbary, 'Famous Trademarks and the Rational Basis for Protecting Irrational Beliefs' (2007) 14 Geo Mason L Rev 605, 620-23; Assaf (n 49) 96-98.

56 Litman (n 49) 1727.

57 See discussion on this in Chapter 6.

58 At the time of writing: Directive (EU) 2015/2436 of the European Parliament and of the Council of 16 December 2015 to approximate the laws of the Member States relating to trade marks [2015] OJ L336/1 and Regulation (EU) 2017/1001 of the European Parliament and of the Council of 14 June 2017 on the European Union trade
} mark [2017] OJ L154/1. 
(EU), ${ }^{59}$ the discussions here in respect of the UK Trade Marks Act 1994 and the law of passing off remain unaffected. ${ }^{60}$

An analysis from the perspective of 'goodwill' within a common law context or a context of the unfair competition principle permits a logical dividing line between substantive goodwill and structural goodwill. It also avoids the ambivalence of seeing trade marks as performing informational functions that are universally viewed by legal scholars as socially beneficial, while at the same time performing persuasive functions that modern trade mark laws in some jurisdictions controversially seek to protect. It also permits a view from the consumer's perspective, regardless of the trader's intentions in its use of the marks or activities in investing in, communicating and advertising with its marks. Substantive goodwill is comprehensive of the consumer's perception of branded goods, such as Lego bricks, regardless of whether that perception is rational or emotional, based on first-hand experience, advertising from traders or commentaries from fans, friends or expert reviewers. Structural goodwill, on the other hand, is a value-neutral consumer recognition of the branded goods (eg, toy bricks, theme parks and movies) as originating from or endorsed by one trader (Lego). The protection of structural goodwill offers a coherence among the 'nooks and crannies' within the law of passing off to protect against misattribution not only in the sale of goods, but also in advertising, merchandising and endorsement, as well as in post-sale contexts, as discussed in Chapter 4.

Consumers need not have had prior exposure to the brand to have this recognition. They may recognize an unfamiliar brand as a new entrant to the marketplace. Structural goodwill helps to inform substantive goodwill by enabling consumers to link up their experiences (if any) with the brand. Protecting structural goodwill in this way, the law of passing off protects both established brands and new entrants to the marketplace.

Drawing a clear plumb line in trade mark laws that is fully rationalized under the law of passing off is also important in the face of increasingly strong and complex statutory protection that is broadly in favour of trade mark owners,

59 Other EU laws may also impact upon the law of passing off - see, for example, Phillip Johnson and Johanna Gibson, 'The "New" Tort of Passing Off' (2015) 131 LQR 476 in respect of the Unfair Commercial Practices Directive (2005/29) OJ L149/22.

60 UK Government, 'Guidance: EU Trade Mark Protection and Comparable UK Trade Marks from 1 January 2021', www.gov.uk/guidance/eu-trademark-protection -and-comparable-uk-trademarks (last accessed 12 August 2020); UK Government, 'Guidance: Changes to EU and International Designs and Trade Mark Protection from 1 January 2021', www.gov.uk/guidance/changes-to-eu-and-international-designs-and -trade-mark-protection-after-the-transition-period (last accessed 12 August 2020). See also Graeme B Dinwoodie and Rochelle Cooper Dreyfus, 'Brexit and IP: The Great Unraveling' (2018) 39 Cardozo L Rev 967. 
as discussed in Chapter 5. Such protection is not always fully rationalized. Legislatures need a clear line of reference to assess whether and to what extent such protection is rationalized and where the trade-offs lie to accommodate other values. As discussed in Chapter 4, the principles that underpin the law of passing off also offer a rationalized framework for assessing the protection offered within newer torts such as the appropriation of personality in Canada and the right of publicity in the US.

A clear distinction between protecting the structural goodwill and the substantive goodwill of a brand is also crucial to facilitate freedom of expression. No trader should have exclusive control over the substantive goodwill that pertains to it or its goods in the marketplace. Pundits, commentators, expert and lay reviewers should be able to express their views about goods in the marketplace as a matter of exercising their freedom of expression. Consumers also have a corresponding right to receive these views, which may inform them in their purchase decision making. Therefore, while traders seldom have exclusive control over substantive goodwill, they should never have such exclusive control. On the other hand, structural goodwill ought to be within the exclusive control of plaintiff traders because traders should not have goods misattributed to them or away from them in ways that are likely to alter consumers' purchase decisions and harm those traders.

Furthermore, this distinction helps to delineate the law of passing off from other intellectual property rights. The law should not protect the attractive force that brings in custom because such protection conflicts with the competitive economic efficiency rationale that underpins the law of passing off, ${ }^{61}$ discussed in Chapter 2. The law of passing off should leave businesses free to copy, create and innovate in ways that do not conflict with the rationales underpinning intellectual property rights such as copyright and patents. As Lego's patents lapse, others should be able to market identical goods without the Lego logo. An English court noted:

There is no tort of copying. There is no tort of taking a man's market or customers. Neither the market nor the customers are the plaintiff's to own. There is no tort of making use of another's goodwill as such. There is no tort of competition. I say this because at times the plaintiffs seemed close to relying on such torts. For instance, [counsel for the plaintiffs] reminded me of the old adage, "Anything worth copying is worth protecting. ${ }^{62}$

${ }^{61}$ Litman (n 49) 1730-31; Irene Calboli, 'The Case for a Limited Protection of Trademark Merchandising’ (2011) 2011 U Ill L Rev 865, 890-91.

62 Hodgkinson \& Corby Ltd v Wards Mobility Services Ltd [1994] 1 WLR 1564 (Ch) 1569-70. See also Australia: Parkdale Custom Built Furniture Proprietary Limited v Puxu Proprietary Limited (1982) 42 ALR 1 (HCA) 23-26. Canada: Kirkbi (n 23) [52]-[54], [67]. US: Big Top USA Inc v Wittern Group 998 F Supp 30 (D Mass 
If the law of passing off veers towards protecting substantive goodwill, it risks barring new market entrants which offer the same attractive features to consumers, but perhaps at a lower price or in combination with other features that render the goods even more desirable to consumers. It also risks interfering with intellectual property laws such as copyright and patents which do award a degree of exclusive control, but with explicit rationales and safeguards to limit the scope of such control.

\section{THE JURISDICTIONS CONSIDERED}

This work centres on Australia, common law Canada, England and Wales and the federal Lanham Act in the US - with occasional references to state and provincial laws - because they all subscribe to a free market economy and operate a version of the law of passing off which evolved at least in part from English law. In all of these jurisdictions, the principle against passing off continues to underpin the law of passing off as it is known in Australia, Canada and England and Wales, and much of their trade mark laws. It also underpins much of trade mark laws and unfair competition law under the Lanham Act in the US.

The jurisprudential ties among Australia, Canada and England and Wales ${ }^{63}$ are strong. Even though the laws in these jurisdictions have developed independently for some time, they continue to make occasional references to each other's jurisprudence. During the most active period in the nascent development of the law of passing off in England, the Judicial Committee of the Privy Council in London was the court of final appeal for Canada until 1949 and for Australia until 1986. The House of Lords, replaced in 2009 by the UK Supreme Court, was the court of final appeal for England and Wales. Regardless of any binding value that the decisions of the Judicial Committee of the Privy Council had on jurisdictions beyond that which brought the appeal in question, the Privy Council's decisions were influential in all jurisdictions for which it was a court of final appeal, as well as in England and Wales, where

1998) 53, citing West Point Manufacturing Co v Detroit Stamping Co 222 F2d 581 (6th Cir 1955) 586.

${ }^{63}$ In the UK, while the law of passing off exists in all parts of England and Wales, Northern Ireland and Scotland, the case law in each of these jurisdictions is not binding on the others. Indeed, the Scots law of passing off is rooted in a different legal foundation from that for the English law of passing off. See also Metric Resources Corporation $v$ Leasemetrix Ltd [1979] FSR 571 (Ch) 575; Catherine W Ng, 'A Common Law of Passing Off? English and Scottish Perspectives’ (2009) 13(1) Edinburgh L Rev 134. 
it was not. ${ }^{64}$ The overall ethos was to have all jurisdictions which adopted the system develop their laws in a consistent way. ${ }^{65}$ Even though the American colonies no longer brought their cases for appeal at the Privy Council after they gained independence in 1776, ${ }^{66}$ Australia, Canada and the US all looked at least in part to English law in developing their own initial jurisprudence on the law of passing off. The development of the law among these jurisdictions was neither uniform nor in lock-step. Furthermore, as discussed in Chapter 5 , reliance on the tort of passing off on the part of the judiciary, litigants and prospective litigants varies depending on the availability and strength of legislative provisions such as those in trade mark laws which offer parallel and often more powerful protection to redress the wrong.

Nevertheless, an analysis of the law in these jurisdictions allows glimpses of potential developments in the common law of passing off overall. The approach here is not a comparison of how these jurisdictions treat the law of passing off. Rather, it is to sketch a family portrait of how each jurisdiction applies the law of passing off and to expose a range of trajectories for the potential development of the law among these jurisdictions.

\section{THE SCOPE AND FORMAT OF THIS WORK}

This work approaches the law of passing off largely from the consumer's perspective. The basic premise is that all parties - traders and consumers alike - benefit from greater availability and reliability of market information that is salient to purchase decision making in the marketplace. Such information includes the origin, availability and endorsing traders of the relevant goods. There is an informational imbalance in business and in law between traders that look to attract custom and consumers who look to optimize their purchases. From a business perspective, traders know more about their goods than their customers do. ${ }^{67}$ From a legal perspective, in a case of passing off, it is consumers who are deceived. Yet few consumers find it sufficiently worthwhile in time, funds and efforts to initiate legal claims against rogue traders.

${ }^{64}$ See, for example, HH Marshall, 'The Binding Effect of Privy Council Decisions' (1968) 17 ICLQ 743; Peter Mirfield, 'Case Comment: A Novel Theory of Privy Council Precedent' (2017) 133 LQR 1.

${ }^{65} R v$ Patents Appeal Tribunal ex Parte Swift \& Co [1962] 2 QB 647, 664 in respect of patents.

66 Sharon Hamby O'Connor and Mary Sarah Bilder, 'Appeals to the Privy Council Before American Independence: An Annotated Digital Catalogue' (2012) 104(1) L Library J 84.

67 Margaret Chon, 'Trademark Goodwill as a Public Good: Brands and Innovations in Corporate Social Responsibility’ (2017) 21 Lewis \& Clark L Rev 277, 303. 
Indeed, they have no right of action to do so under the law of passing off. Yet, as discussed in Chapter 2, the law carries a mandate of protecting both traders and consumers. By protecting the interests of traders against unfair competition, the law also aims to protect consumers. From a business standpoint, to succeed in attracting custom, traders must approach the market with an appreciation of the consumer's perspective. They must appeal to consumers with attractive features to influence their purchase decisions. ${ }^{68}$ The law must protect those features from being misattributed to other traders and protect consumers from deception and confusion.

This work proceeds as follows: Chapter 2 sets out a brief overview of the development of the law of passing off. It then poses the inherent conflict between the rationales for protecting structural goodwill and for protecting substantive goodwill. It analyses the position that the law of passing off occupies vis-à-vis other intellectual property laws. It then critiques the widely accepted consumer search costs theory, which purports to underpin protection against passing off. It proposes a market information theory that will be applied throughout this work. Chapter 3 fleshes out the argument that the attractive force that brings in custom or substantive goodwill is seldom the construct of any one trader alone. Instead, it is usually the construct of multi-directional social dialogues among traders, consumers and commentators. The chapter challenges the traditional one-way, trader-to-consumer broadcast view of branding. It illustrates how brand values are conveyed and how substantive goodwill mutates in the marketplace. Chapter 4 argues that protecting traders' structural goodwill is the consistent and coherent thread that underpins the law of passing off. It shows how the law of passing off applies to the sale of goods, advertising, merchandising, endorsements and the post-sale context to help traders shape the substantive goodwill that pertains to them in the multi-directional social dialogues set out in Chapter 3. Chapter 5 analyses trade mark and related legislation to highlight the problems in protecting substantive goodwill on its own. It also places the law of passing off in the broader legislative context in which the law operates. Chapter 6 poses an example where the law of passing off applies without implicating any substantive goodwill. It illustrates how a focus on protecting structural goodwill can avoid issues vis-à-vis other intellectual property rights. Chapter 7 concludes by reflecting on the points established in the earlier chapters.

\footnotetext{
68 Desai (n 18) 1001.
} 